\title{
Teachers' Training Course Using Synchronous Conferencing Tools for Hospitality and Tourism Education in Vietnam: A Constructivist Approach
}

\author{
Thanh-Thao Luong and Eunyoung Kim
}

\begin{abstract}
Despite its significant damage to the hospitality and tourism industry, the pandemic of COVID-19 indeed has reinforced the needs for not only the hospitality and tourism education, but also the whole educational system of Vietnam, to make use of technological innovations in education, among which synchronous conferencing tools are currently utilized for changing their mode from physical classroom to online learning. This study adopts the constructivist approaches to propose a training course designed to enhance the skills needed for teaching with synchronous conferencing technology for teachers in Vietnam's hospitality and tourism institutions. We based on the current literature to identify the necessary skills to implement classes via synchronous conferencing environments. We also selected and designed learning activities to translate constructivist teaching theory into online pedagogies. Although it needs to be evaluated in further studies, this course design is expected to contribute to the growing literature on methods to improve instructors' readiness to teach in virtual classrooms.
\end{abstract}

Index Terms - Constructivist approach, teacher training, web-based synchronous conferencing.

\section{INTRODUCTION}

Since the COVID-19 pandemic forced schools in Vietnam to move their classes online to avoid spreading the virus, the use of remote conferencing platforms has soared in popularity. Nevertheless, research and current reports indicate that the use of information-communication technology in teaching is still limited and varied among institutions in Vietnam [1]. Therefore, teachers are facing challenges in moving their work from traditional face-to-face classrooms to virtual ones. These challenges are referred to not only as the technical restrictions such as the quality of internet connection required for the online learning system but also as instructors' readiness in teaching via online learning environments. This situation is consistent with the literature about the needs to provide teacher training in using a technological tool to deliver lessons in a virtual learning environment.

\section{RESEARCH OBJECTIVES}

In this paper, we adopt the three aspects of constructivism discussed by [2] to propose a training program for Hospitality

Manuscript received July 9, 2020; revised January 26, 2021. This work was supported by Japan Advanced Institute of Science and Technology.

The authors are with the Japan Advanced Institute of Science and Technology (JAIST), Nomi, Ishikawa, 923-1292, Japan (e-mail: luong.thanh.thao@jaist.ac.jp, kim@jaist.ac.jp). and Tourism instructors working in institutions in Vietnam. These aspects are "knowledge is constructed by learners, knowledge is experience-based, and a strong class community is essential". The course aims at enhancing the level of participants' self-evaluation in using synchronous conferencing tools for teaching.

\section{RELATED WORKS}

\section{A. Skills Needed for Online Teaching}

Current literature indicates that instructors need to be provided with sufficient training and resources to be confident in teaching in synchronous conferencing environments [3]-[6]. K. Kear [4] also stress that even teachers who are experienced in distance teaching still need to be equipped with adaptive pedagogies. Also, to make such training more productive, identifying which parts of knowledge are in the training gaps becomes essential. Numerous researchers have outlined different skill sets required for teachers to perform effectively in online synchronous classes. These skills are listed in Table I.

TABLE I: SKILL COMPLEXES REQUIRED FOR TEACHING IN SYNCHRONOUS CONFERENCING CLASSES

\begin{tabular}{ll}
\hline \hline Skills & Description \\
\hline $\begin{array}{l}\text { Developing Online } \\
\text { Presence }\end{array}$ & $\begin{array}{l}\text { Recognizing the importance of online presence [4], } \\
\text { [5] [7]-[14] and strategies to enhance social, } \\
\text { teaching, and cognitive presence in virtual } \\
\text { classrooms [8], [15], [16]. }\end{array}$ \\
\hline Planning Lessons & $\begin{array}{l}\text { Preparing learners before the course starts and } \\
\text { designing learning activities [4], [5], [8], [17], [18]. }\end{array}$ \\
\hline $\begin{array}{l}\text { Handling } \\
\text { Technology }\end{array}$ & $\begin{array}{l}\text { Using different functionality of synchronous } \\
\text { conferencing platforms to achieve learning } \\
\text { outcomes [3], [5], [11], [19]. }\end{array}$ \\
\hline $\begin{array}{l}\text { Adapting to } \\
\text { Learners' } \\
\text { Preferences }\end{array}$ & $\begin{array}{l}\text { Recognizing varied learning preferences and } \\
\text { learners' diverse backgrounds [8], [12], [20], [21] to } \\
\text { identify supportive technological resources and } \\
\text { tools [8], [20], [21]. }\end{array}$ \\
\hline $\begin{array}{l}\text { Classroom } \\
\text { Management }\end{array}$ & $\begin{array}{l}\text { Developing strategies to respond to learners' } \\
\text { behaviors and manage virtual classrooms [5], [8], } \\
\text { [22], [23]. }\end{array}$ \\
\hline \hline
\end{tabular}

Nonetheless, current literature on this topic has indeed focused more on the field of language training than any other professional areas. Therefore, more research is needed to instruct teachers in other disciplines in making use of synchronous conferencing tools.

\section{B. Constructivist Approaches to Online Teacher} Training in Using Technology

According to cognitive constructivists, knowledge is 
constructed via the interweaving processes of assimilation and accommodation occurring during an individual's development. While the former process refers to the addition of new information, the latter is defined as how a learner restructures his or her prior knowledge so that new knowledge can be established appropriately [24]. These dual processes stem from environmental problems that do not fit in an individual's accumulated knowledge [25]. When discussing the cognitive constructivist views in teacher education, C. Kosnik [2] suggests that if teachers experience constructivist approaches as students, there is a possibility that they will adopt this approach in their teaching. These teachers will later attempt to replace lecture-driven classes with a more learner-centered atmosphere. Unlike the cognitive constructivist approach, social constructivism focuses on the influence of cultural and environmental settings on how individuals construct their new knowledge [24]. In other words, knowledge construction takes place when an individual communicates with others, such as instructors, experts, or peers, in an authentic environment that may be simulated from reality. Despite their differences, both cognitive and social constructivism has been adopted and recommended by numerous researchers in the field of teacher education, e.g., [2], [24]. Current literature highlights that studies should investigate the interactions between social environment and individual knowledge construction rather than focusing on determining which theory should be given more preference in the field of learning analysis [24], [26]. What is genuinely associated with "a strong class community", according to [2], is to strengthen the professional relationships among class participants through activities such as open discussions, collaboration, working together, experiencing each other's work, and offering constructive and supportive feedback to each other. Such a safe and supportive learning community has been proved in numerous studies to enhance teachers' confidence in teaching with new technology [2], [24], [27], [28].

Constructivism is also widely adopted in studies about online training programs for teachers. For example, [9] refer to the implementation of the social constructivist approach in designing their online workshop for pre-service teachers as a success story. Similarly, S. Cornelius [5] highlights that constructivism, when practiced in a virtual classroom, may offer more interaction among participants and thus generate more student engagement and ownership. S. B. Eom [12] also assert that "the defining characteristics of e-learning are derived from the constructivist model of learning". These authors cited [29] to endorse the view that constructivism has been a sound theoretical framework for research on virtual learning settings.

\section{Teachers' Training Programs Using Synchronous Conferencing Technology}

There have been few studies in which teachers' training programs in teaching via synchronous conferencing environments were conducted and reported in detail. Most research on training for teaching with technology generally focuses on both asynchronous and synchronous tools. However, the latter is claimed to provide more meaningful communication and interaction conducive to online learning.
Table II lists studies that focus on teachers' training in using synchronous technology and their limitations.

TABLE II: LIMITATIONS OF STUDIES FOCUSING ON TEACHERS’ TRAINING IN USING SYNCHRONOUS TECHNOLOGY

\begin{tabular}{ll}
\hline \hline Content & Limitations \\
\hline $\begin{array}{l}\text { Theoretical } \\
\text { Framework }\end{array}$ & $\begin{array}{l}\text { Lack of details on theoretical background [9], [18], } \\
{[30] .}\end{array}$ \\
\hline $\begin{array}{l}\text { Synchronous } \\
\text { Platform }\end{array}$ & $\begin{array}{l}\text { Few details and explanation on why and how the } \\
\text { platform chosen for the studies [9], [10], [17], [18], } \\
{[30] .}\end{array}$ \\
\hline Course content & $\begin{array}{l}\text { Lack of details about course objectives, structure, } \\
\text { and content [17], [18], [31]. }\end{array}$ \\
\hline $\begin{array}{l}\text { Implementation of } \\
\text { the Programs }\end{array}$ & $\begin{array}{l}\text { Scarcity of details on how the training program was } \\
\text { implemented and how synchronous conferencing } \\
\text { technology contributes to the success of the training } \\
\text { [9], [17], [31]. }\end{array}$ \\
\hline $\begin{array}{l}\text { Evaluation of the } \\
\text { Program }\end{array}$ & $\begin{array}{l}\text { Most studies claimed programs' success, yet there } \\
\text { were few details on how evaluation methods were } \\
\text { designed for the studies [9], [10]. }\end{array}$ \\
\hline \hline
\end{tabular}

\section{Course DESIGN}

\section{A. Course Design Framework}

We adopt the three aspects of constructivism discussed by [2] as "knowledge is constructed by learners", "knowledge is experience-based", and "a strong class community is essential" to design the training program for this study. Table III shows the course learning activities, which are expected to improve participants' self-evaluation in skill complexes required for teaching with synchronous conferencing technology. These skills include those mentioned in Table I.

TABLE III: DESCRIPTION OF THE COURSE'S LEARNING ACTIVITIES

\begin{tabular}{|c|c|}
\hline $\begin{array}{l}\text { Learning } \\
\text { Activities }\end{array}$ & How to Conduct \\
\hline Online Icebreaker & $\begin{array}{l}\text { An online icebreaker is conducted in the first session } \\
\text { to get participants to know each other and stimulate } \\
\text { conversations. }\end{array}$ \\
\hline $\begin{array}{l}\text { Collaborative } \\
\text { Brainstorming }\end{array}$ & $\begin{array}{l}\text { Participants are required to generate new ideas and } \\
\text { solutions around a specific issue. }\end{array}$ \\
\hline Group Discussions & $\begin{array}{l}\text { Each group discussion takes } 10-15 \text { minutes and is } \\
\text { designed to exchange ideas. }\end{array}$ \\
\hline Teaching Practice & $\begin{array}{l}\text { Each participant practices designing learning } \\
\text { activities and teaching. }\end{array}$ \\
\hline Self-Reflection & $\begin{array}{l}\text { After teaching-practice sessions, participants collect } \\
\text { information for reviewing. A self-reflective journal } \\
\text { template is provided for participants to note down } \\
\text { their feelings, observations, and questions. }\end{array}$ \\
\hline $\begin{array}{l}\text { Inquiry-based } \\
\text { Instruction }\end{array}$ & $\begin{array}{l}\text { Participants' questions or problems drive the } \\
\text { discussion to develop solutions. }\end{array}$ \\
\hline $\begin{array}{l}\text { Modeling and } \\
\text { Unpacking }\end{array}$ & $\begin{array}{l}\text { The facilitator models a designed activity to assist } \\
\text { learning, then makes this activity explicit by letting } \\
\text { participants discuss the activity afterward. }\end{array}$ \\
\hline Educational games & $\begin{array}{l}\text { Online interactive quizzes, puzzles, and games are } \\
\text { designed to help participants learn about concepts. }\end{array}$ \\
\hline Role-play & $\begin{array}{l}\text { Before role-playing, participants are required to } \\
\text { research the topic, study roles in the situation } \\
\text { presented. Hence, group discussions are held to } \\
\text { consolidate learning. }\end{array}$ \\
\hline Peer feedback & $\begin{array}{l}\text { During teaching-practice sessions, peer observations } \\
\text { are facilitated with the rubric. }\end{array}$ \\
\hline
\end{tabular}

We also created Fig. 1 below to integrate the learning activities in Table III with these skills. This integration helps characterize the course design framework. 


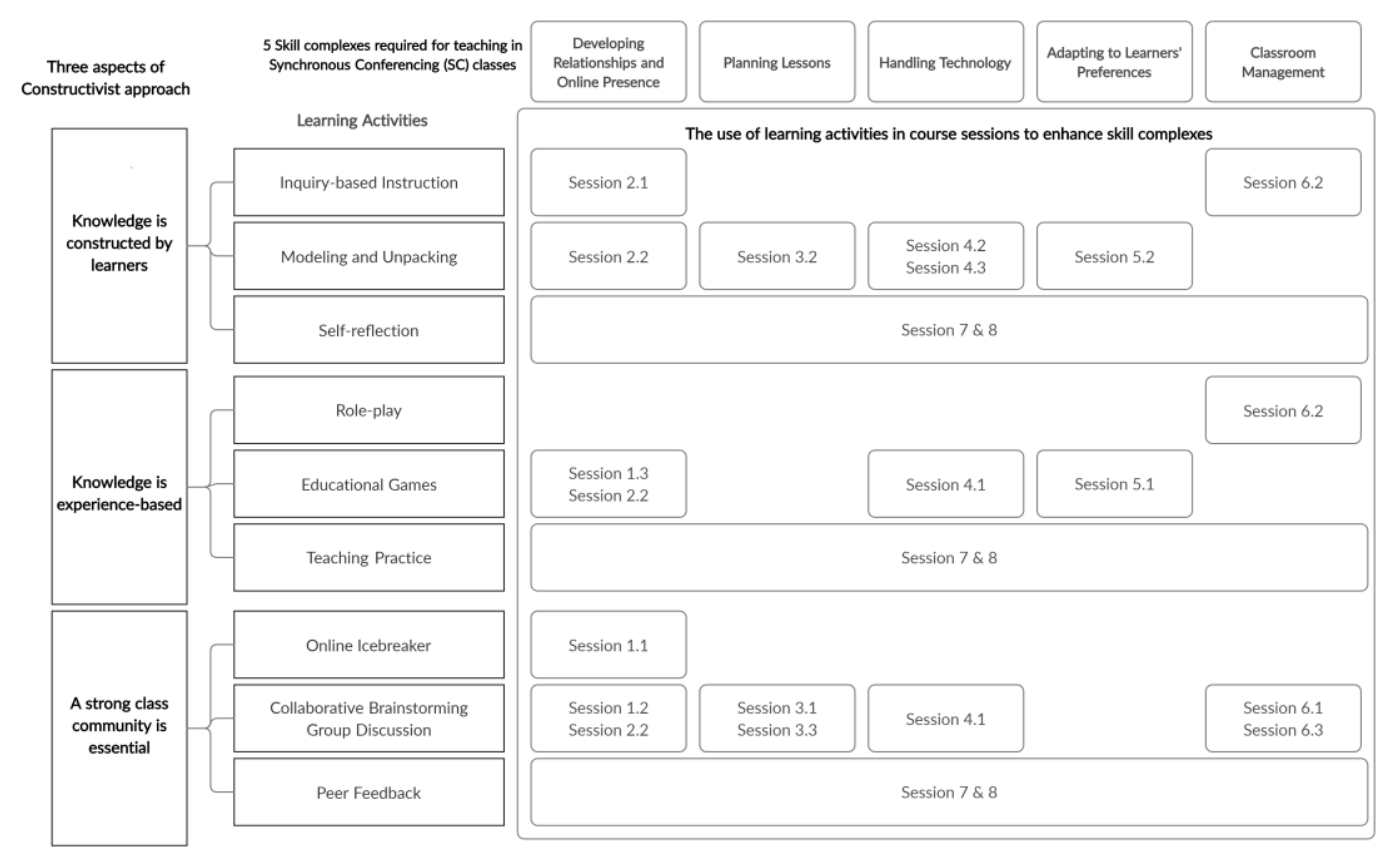

Fig. 1. Course design framework based on three constructivist aspects.

TABLE IV: COURSE STRUCTURE AND DESCRIPTION

\begin{tabular}{|c|c|c|c|c|}
\hline Session & \multicolumn{2}{|r|}{$\begin{array}{c}\text { Learning Outcomes } \\
\text { (What participants can do after each session) }\end{array}$} & Learning Activities & $\begin{array}{l}\text { Duration } \\
\text { (minutes) }\end{array}$ \\
\hline \multirow{3}{*}{ Course Introduction } & 1.1 & $\begin{array}{l}\text { Get to know each other and have an open atmosphere for } \\
\text { learning and collaborating. }\end{array}$ & Online Icebreaker & 40 \\
\hline & 1.2 & Discuss course structure and objectives. & Group Discussion & 20 \\
\hline & 1.3 & Compare asynchronous with synchronous online learning. & Educational Game (Kahoot) & 30 \\
\hline \multirow{2}{*}{$\begin{array}{l}\text { Developing Online } \\
\text { Presence }\end{array}$} & 2.1 & $\begin{array}{l}\text { Define three types of online presence: social, teaching, } \\
\text { cognitive presence. }\end{array}$ & $\begin{array}{l}\text { Inquiry-based instruction } \\
\text { Educational game (Kahoot) }\end{array}$ & 45 \\
\hline & 2.2 & Develop methods to enhance online presence. & $\begin{array}{l}\text { Collaborative Brainstorming } \\
\text { Modeling and Unpacking }\end{array}$ & 45 \\
\hline \multirow{3}{*}{ Planning Lessons } & 3.1 & $\begin{array}{l}\text { Describe what constructs quality educational experience in } \\
\text { online learning. }\end{array}$ & $\begin{array}{c}\text { Group Discussion } \\
\text { Collaborative Brainstorming }\end{array}$ & 20 \\
\hline & 3.2 & $\begin{array}{l}\text { Create steps to prepare learners before launching online } \\
\text { courses. }\end{array}$ & Modeling and Unpacking & 30 \\
\hline & 3.3 & Design synchronous learning activities. & $\begin{array}{l}\text { Group Discussion } \\
\text { Collaborative Brainstorming }\end{array}$ & 40 \\
\hline \multirow{3}{*}{$\begin{array}{l}\text { Handling } \\
\text { Technology }\end{array}$} & 4.1 & List factors to consider when selecting a learning platform. & $\begin{array}{l}\text { Collaborative Brainstorming } \\
\text { Group Discussion }\end{array}$ & 20 \\
\hline & 4.2 & Use softwares, applications for real-time teaching. & Modeling and Unpacking & 45 \\
\hline & 4.3 & $\begin{array}{l}\text { Use different synchronous features to implement learning } \\
\text { activities. }\end{array}$ & $\begin{array}{l}\text { Modeling and Unpacking } \\
\text { Peer feedback }\end{array}$ & 45 \\
\hline \multirow{2}{*}{$\begin{array}{l}\text { Adapting to } \\
\text { Learners' } \\
\text { Preferences }\end{array}$} & 5.1 & Address varied learning styles. & Educational quizzes (Google form) & 30 \\
\hline & 5.2 & $\begin{array}{l}\text { Identify resources and tools for matching with different } \\
\text { learning styles. }\end{array}$ & $\begin{array}{l}\text { Modeling and Unpacking } \\
\text { Teaching practice }\end{array}$ & 60 \\
\hline \multirow{3}{*}{$\begin{array}{l}\text { Classroom } \\
\text { Management }\end{array}$} & 6.1 & Compare online and offline classroom management. & Group Discussion & 20 \\
\hline & 6.2 & $\begin{array}{l}\text { Apply techniques to give constructive and corrective } \\
\text { feedback to online learners. }\end{array}$ & Inquiry-based instruction, Role-play & 30 \\
\hline & 6.3 & $\begin{array}{l}\text { Develop strategies to respond to learners' behaviors or } \\
\text { misbehaviors. }\end{array}$ & $\begin{array}{c}\text { Group discussion } \\
\text { Collaborative brainstorming } \\
\end{array}$ & 40 \\
\hline Teaching Practice & \multicolumn{2}{|r|}{ Participants practice teaching, self-reflection, and peer-feedback. } & $\begin{array}{l}\text { Teaching practice, Self Reflection } \\
\text { Peer feedback }\end{array}$ & $\begin{array}{c}15 \\
\text { minutes/ } \\
\text { participant }\end{array}$ \\
\hline
\end{tabular}

\section{B. Selecting a Platform}

To choose an appropriate platform, the authors of this study propose two dimensions for categorizing online classrooms, which can be conducted via currently available platforms. The first dimension is the epistemological approaches in education, referring to the teacher-centered or the learner-centered approach. Whether a platform becomes more supplements to the former or the latter approach depends on their currently built-in features. If such features could enable instructors to play the following critical roles mentioned by [32], they might be promising for a student-centered classroom.

1) keeping records of what each student has mastered, what is within reach to work on next, and what characteristics each student has that should influence instruction;

2) helping to create each student's personal learning plan;

3) providing an immerse, authentic project environment with just-in-time instructional support; formatively and summatively assessing mastery of each student's learning goals. 
The second dimension for the classification of online classes to be supported by synchronous conferencing platforms is classroom size, which is defined as the number of students in a course. L. Jones [33] highlights that the optimum number of students in a student-centered language training class is 12 and the maximum size for such a class is 30 . In this study, we consider a classroom size ranging from 12 to 30 learners a small-size one, and a large one could range from more than 30 to 100 students.

We created Fig. 2 to demonstrate different types of classrooms to be conducted with video conferencing platforms and which platforms are most suitable for different types of these online classes. As shown in Fig. 2, synchronous classes under the teacher-centered approach are named "Live University Lectures", indicating that instructors in these classes tend to deliver lectures or presentations merely. Large-size classes that adopt the learner-centered approach are "Independent Learning Groups"; this title was mentioned by [34] to refer to large class settings under the student-centered paradigm. Courses with a smaller number of students where instructors tend to have students listen passively to obtain knowledge are entitled "Online Seminars. Small-size classes, if conducted with students actively engaged in knowledge construction, are named "Online Student-Centered Classrooms". Although this categorization is based only on our experiences of these platforms, it shows an example of how administrators or instructors can make a decision on which platform can be used for learning. Noticeably, some platforms have numerous features that may enable instructors to work either under a teacher-centered or a learner-center paradigm, e.g., Coursesites, Cisco Webex, Zoom, or Microsoft Teams.

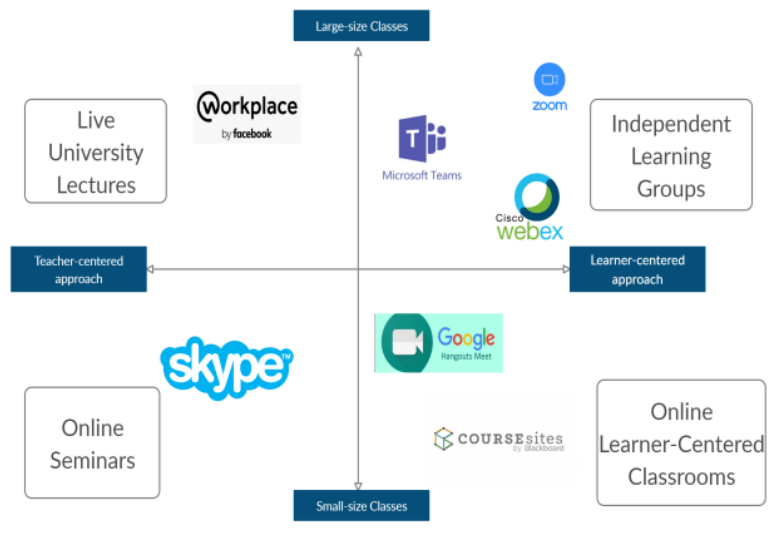

Fig. 2. Synchronous platforms matched with types of online classes.

As the proposed course is designed under the constructivist approaches and the class's intended size is less than 10, an "Online Students-Centered Classroom" model appears to best match with the purpose of the study. Thus, the authors of this study decided to use the classroom version of Blackboard Collaborate since it has all the built-in features designed to best support this type of online class. We also used the free version of Blackboard Coursesites as a Learning Management System (LMS) to provide course materials, communicate with participants, encourage collaboration, monitor performance, and manage attendance or performance. While the Vietnamese Ministry of Education and Training (MOET) has not yet issued legal documents instructing schools on integrating online teaching technology into educational curricula, a free course management service designed mainly for teaching appears to be the optimum choice.

\section{Course Structure}

The course consists of 8 online synchronous sessions; each lasts 90 minutes. The first session introduces the course and its objectives. The next five sessions aim to improve participants' levels of knowledge and skills in teaching via a synchronous conferencing environment. In session 7 and 8 , participants are required to design learning outcomes and activities to practice teaching using different real-time technological tools. Details on the learning outcomes and activities are listed in Table IV below.

\section{CONCLUSION}

As this proposed course was built upon the currently urgent needs raised by most teachers in Vietnam, it will soon be implemented to improve teachers' readiness in teaching with synchronous technological tools in online learning environments. 100 participants, who are in-service teachers working at various hospitality and tourism institutions in Vietnam, will be recruited for course implementation and evaluation.

Since the current study lacks empirical evidence, the authors will adopt qualitative and quantitative analysis in their further study to assess the impact of the proposed course. It is expected that our proposal in the course design will contribute to the growing literature on methods to utilize constructivist teaching theory in online pedagogies and accordingly improve instructors' readiness to teach in virtual classrooms.

\section{CONFLICT OF INTEREST}

The authors declare no conflict of interest in carrying out this research.

\section{AUTHOR CONTRIBUTIONS}

Thanh-Thao Luong carried out the literature review, course design, and manuscript drafting. Eunyoung Kim was involved in revising it critically and giving final approval of the version to be submitted. All authors read and approved the final manuscript.

\section{REFERENCES}

[1] X. T. Dang, "ICT in foreign language teaching in an innovative university in Vietnam: Current practices and factors affecting ICT use statement of authorship," Ph.D. dissertation, Faculty of Education, Melbourne, La Trobe University, Australia, 2013.

[2] C. Kosnik, L. Menna, P. Dharamshi, and C. Beck, "Constructivism as a framework for literacy teacher education courses: The cases of six literacy teacher educators," European Journal of Teacher Education, vol. 41, no. 1, pp. 105-119, 2018, DOI: 10.1080/02619768.2017.1372742.

[3] M. M. Grant and J. Cheon, "The value of using synchronous conferencing for instruction and students," Journal of Interactive Online Learning, vol. 6, no. 3, pp. 211-226, 2007.

[4] K. Kear, F. Chetwynd, J. Williams, and H. Donelan, "Web conferencing for synchronous online tutorials: Perspectives of tutors 
using a new medium," Computers \& Education, vol. 58, no. 3, pp. 953-963, 2012, DOI: 10.1016/j.compedu.2011.10.015.

[5] S. Cornelius, "Facilitating in a demanding environment: experiences of teaching in virtual classrooms using web conferencing," British Journal of Educational Technology, vol. 45, no. 2, pp. 260-271, 2014, DOI: $10.1111 /$ bjet.12016.

[6] R. C. S. Yee, "Perceptions of online learning in an australian university: Malaysian students' perspective - support for learning," International Journal of Information and Education Technology, vol. 5, no. 8, pp. 587-592, 2015, DOI: 10.7763/ijiet.2015.v5.573.

[7] E. H. Bacon and L. A. Bloom, "Beyond the herring sandwich phenomenon: A holistic constructivist approach to teacher education," Journal of Learning Disabilities, vol. 28, no. 10, pp. 636-645, 1995, DOI: $10.1177 / 002221949502801005$.

[8] J. V. Boettcher and R.-M. Conrad, The Online Teaching Survival Guide: Simple and Practical Pedagogical Tips, 2nd Editio. San Francisco: Jossey-Bass, 2016

[9] A. d'Eça and D. Gonzáles, "Becoming a webhead: Bridging the gap from classroom to blended or online teaching," CALICO Journal, vol. 23, no. 3, pp. 569-580, 2006, DOI: 10.1558/cj.v23i3.569-580.

[10] Y. Wang, N. S. Chen, and M. Levy, "Teacher training in a synchronous cyber face-to-face classroom: characterizing and supporting the online teachers' learning process," Computer Assisted Language Learning, vol. 23, no. 4, pp. 277-293, 2010, DOI: $10.1080 / 09588221.2010 .493523$.

[11] P. Ernest, S. Heiser, and L. Murphy, "Developing teacher skills to support collaborative online language learning," Language Learning Journal, vol. 41, no. 1, pp. 37-54, Apr. 2013, DOI: 10.1080/09571736.2011.625095.

[12] S. B. Eom and N. Ashill, "The determinants of students' perceived learning outcomes and satisfaction in university online education: An update," Journal of Innovative Education, vol. 14, no. 2, pp. 185-215, 2016.

[13] K. Lee, "Everyone already has their community beyond the screen: Reconceptualizing online learning and expanding boundaries," Educational Technology Research and Development, vol. 66, no. 5, pp. 1255-1268, 2018, DOI: 10.1007/s11423-018-9613-y.

[14] A. Després-Bedward, T. L. Avery, and K. Phirangee, "Student perspectives on the role of the instructor in face-to-face and online learning," International Journal of Information and Education Technology, vol. 8, no. 10, pp. 706-712, 2018, DOI: 10.18178/ijiet.2018.8.10.1126.

[15] P. A. Wang, "Assessment of asynchronous online discussions for a constructive online learning community," International Journal of Information and Education Technology, vol. 5, no. 8, pp. 598-604, 2015, DOI: $10.7763 /$ ijiet.2015.v5.575.

[16] L. H. Goh, "The gathering of the community of inquiry in online learning," International Journal of Information and Technology, vol. 10 , no. 7, pp. 494-499, 2020, DOI: 10.18178/ijiet.2020.10.7.1413

[17] V. Grenon, F. Lafleur, and G. Samson, "Developing the techno-pedagogical skills of online university instructors," International Journal of e-Learning \& Distance Education, vol. 34, no. 2, pp. 1-15, 2019.

[18] K. Kannan and K. Narayanan, "A qualitative analysis of synchronous distance mode teacher training workshop," in Proc. - 2016 International Conference on Learning and Teaching in Computing and Engineering LaTiCE 2016, no. June 2012, pp. 99-106, 2016, DOI: 10.1109/LaTiCE.2016.22.

[19] E. Alqurashi, E. N. Gokbel, and D. Carbonara, "Teachers' knowledge in content, pedagogy and technology integration: A comparative analysis between teachers in Saudi Arabia and the United States," British Journal of Educational Technology, vol. 48, no. 6, pp. 1414-1426, 2017, DOI: 10.1111/bjet. 12514.

[20] C. J. Bonk and K. Zhang, Empowering Online Learning: 100+ Activities for Reading, Reflecting, Displaying, and Doing, San Francisco: John Wiley \& Sons, Inc., 2008.

[21] Q. Min, Y. Chen, N. Liu, and M. Zuo, "A learning style model designed for online learning environments," International Journal of Information and Education Technology, vol. 8, no. 9, pp. 623-627, 2018, DOI: 10.18178/ijiet.2018.8.9.1111.

[22] J. G. Pyke and J. J. Sherlock, "A closer look at instructor-student feedback online: A case study analysis of the types and frequency," MERLOT Journal of Online Learning Teaching, vol. 6, no. 1, pp. 110-121, 2010.

[23] O. Kaosaiyaporn, W. Atisabda, J. Plodkaew, and J. Promrak, "Factors of virtual classroom to enhance online learning in multicultural society for pre-service teacher students," International Journal of Information and Education Technology, vol. 5, no. 7, pp. 502-506, 2015, DOI 10.7763/ijiet.2015.v5.557.

[24] L. Wang and A. S. Ha, "Factors influencing pre-service teachers' perception of teaching games for understanding: A constructivist perspective," Sport, Education and Society, vol. 17, no. 2, pp. 261-280, 2012, DOI: 10.1080/13573322.2011.607954.

[25] J. Piaget, "Piaget's theory," Piaget and His School, Springer Berlin Heidelberg, 1976, pp. 11-23.

[26] C. T. Fosnot, Constructivism: Theory, Perspectives, and Practice, 2nd ed. New York: Teachers College Press, 2005.

[27] J. B. Arbaugh and R. Benbunan-Fich, "An investigation of epistemological and social dimensions of teaching in online learning environments," Academy of Management Learning \& Education, vol. 5, no. 4, pp. 435-447, 2006, DOI: 10.5465/AMLE.2006.23473204.

[28] A. Saidalvi and A. A. Samad, "Online peer motivational feedback in a public speaking course," GEMA Online Journal of Language Studies, vol. 19, no. 4, pp. 258-277, 2019, DOI: 10.17576/gema-2019-1904-14.

[29] D. Jonassen, M. Davidson, M. Collins, J. Campbell, and B. B. Haag, "Constructivism and computer-mediated communication in distance education," American Journal of Distance Education, vol. 9, no. 2. 1995.

[30] K. Kannan and K. Narayanan, "Synchronous teacher training in India: A study of perceptions and satisfaction of the participants," International Journal of Information and Education Technology, vol. 5, no. 3, pp. 200-207, 2015, DOI: 10.7763/ijiet.2015.v5.502.

[31] T. E. Johnson, G. H. Maring, J. H. Doty, and M. Fickle, "Cybermentoring: Evolving high-end video conferencing practices to support preservice teacher training," Journal of Interactive Online Learning, vol. 5, no. 1, pp. 59-74, 2006, DOI 10.1017/CBO9781107415324.004.

[32] C. M. Reigeluth, "The learner-centered paradigm of education: Roles for technology," Educational Technology, vol. 54, no. 3, pp. 18-21, 2014.

[33] L. Jones, Student-Centered Classrooms,s New York: Cambridge University Press, 2007

[34] J. Scott, J. Buchanan, and N. Haigh, "Reflections on student-centred learning in a large class setting," British Journal of Educational Technology, vol. 28, no. 1, pp. 19-30, 1997.

Copyright $\odot 2021$ by the authors. This is an open access article distributed under the Creative Commons Attribution License which permits unrestricted use, distribution, and reproduction in any medium, provided the original work is properly cited (CC BY 4.0).

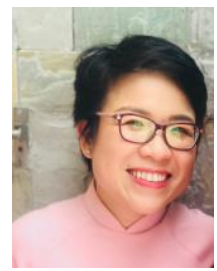

Thanh-Thao Luong holds a master's degree in human resources management from Griffith University, Australia in 2010, and a bachelor's degree in business administration from University of Economics Ho Chi Minh City, Vietnam in 2007. She is currently pursuing her doctoral degree under KIM Lab. in School of Knowledge Science at Japan Advanced Institute of Science and Technology, Japan. Her research interests are in the areas of innovations in hospitality and tourism education. Thao is also a hospitality trainer (CHT) and educator (CHE) certified by the Educational Institute of the American Hotel and Lodging Association (AHLEI), USA. In more than ten years working in the service industry, Thao held different positions in the Human Resources Department at Saigontourist Group, one of the largest hospitality and tourism enterprises in Vietnam, before being appointed as the Vice-Principal at Saigontourist Hospitality College (STHC) in 2016. At Saigontourist Group, Thao was in charge of devising and implementing strategies to ensure professional development for over 200 middle managers and supervisors within the company's properties across Vietnam. During her tenure at STHC, she was in charge of managing various vocational college core activities, including curriculum design, teacher education, international relations, and student recruitment.

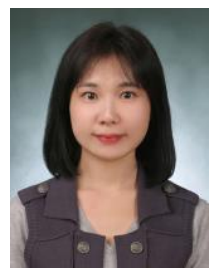

Eunyoung Kim was born in Korea. Her research interests include learning process design for creating innovations. She holds a Ph.D. degree in engineering from the University of Tokyo in 2015, Japan, and a master's degree in international commerce from Seoul National University, Korea in 2009. During her graduate school, she also studied at the project Humtc at RWTH Aachen University, Germany as a doctoral research fellowship awardee in 2012, doctoral program of digital contents and information studies at the Graduate School of Convergence Science and Technology, Seoul National University in 2011, Sam Nunn School of 
International Affairs in Georgia Institute of Technology, GA, the USA in 2006 as an exchange student.

She is an associate professor in the School of Knowledge Science, Japan Advanced Institute of Science and Technology, Japan since 2017. She is an author of various publication related to innovation education: Analogical Thinking for Generation of Innovative Ideas: An Exploratory Study of Influential Factors (CA, USA, IJIKM, 2016); Workshop design for enhancing the appropriateness of idea generation using analogical thinking (International Journal of Innovation Studies, 2017); On designing a cybersecurity educational program for higher education (Tokyo, Japan, Proceedings of the 10th ICETC, 2018). She established the KIM Lab in 2017 at Human Life Design Area of Japan Advanced Institute of Science and Technology, Ishikawa Japan for conducting research in enhancing creativity and innovation skills through designing educational process.

Prof. Kim is a member of Design Society, Japan Creativity Society, and Asia Pacific Institute of Science and Engineering. 